
Ana-Maria VESA-DOBRE

Expresivitatea structurilor spatiale

atipice

The expressivity of atypical spatial

structures 


\section{Expresivitatea structurilor spațiale atipice}

\section{The expressivity of atypical spatial structures}

\section{Ana-Maria VESA-DOBRE}

ana.vesa@gmail.com

Lector Dr.Arhitect, SP*, FA UAUIM Lecturer Dr.Architect, SP*, FA UAUIM

*Departament Sinteza Proiectării de Arhitectură Facultatea de Arhitectură Universitatea de Arhitectură și Urbanism lon Mincu UAUIM București
*Synthesis of Architectural Design Department (SP) Faculty of Architecture Ion Mincu University of Architecture and Urbanism UAUIM Bucharest

\section{rezumat}

Prezentarea acestor tipuri de configurații spațiale nu are pretenția de a epuiza tema, cu atât mai puțin tendințele acesteia, ci doar punctează câteva dintre aspectele predominante ale subiectului. Ideile descrise aici au fost dezvoltate partial și în prelegerile anterioare de atelier (anii univ. IV-V, între 2013 și 2018), pentru proiectele de Pavilion experimental (Cameră urbană), Info-Point, Catalizator urban (K) și Sală de sport (Clădiri cu structuri complexe și deschideri mari), fiind o sursă bună de familiarizare a studenților cu noile programe sau cu tehnologii recente, utilizate în domeniu, dar și un bun punct de pornire în demersul lor conceptual.

\section{cuvinte cheie}

structuri speciale, arhitectură, educație academică abstract

In the end, the presentation does not exhaust the theme, nor its tendencies, but rather points out some general lines of the subject. Some of these ideas were also described in the previous studio lectures of the 4th and 5th years (2013 - 2018), involving the projects Experimental Pavilion / Urban Room, Info-Point, K Urban Catalyser and Sports Hall (Complex Structure and WideSpan Buildings). They proved to be a good starting reference point for the students, while they were getting accustomed to the new typologies of programes and recent structure developing technologies. For their conceptual approach, the lectures were intended to guideline the topic specific tendencies, being joined with model research and studies, at various scales and detail. keywords

special structures, architecture, academic education 
Structura unui obiect arhitectural este un ansamblu de elemente orizontale și verticale, interconectate astfel încât să asigure rezistența volumului la toate solicitările exercitate asupra sa (greutate gravitațională, încărcări uzuale funcționale, inclusiv compartimentări și instalații, vânt, zăpadă, cutremur etc). Selecția unui anumit tip de structură spațială depinde direct de mai mulți factori, acceptați simultan ca fiind necesari: rezistența fizică, condiții tehnice, climatice și de mediu (condiționări ale amplasamentului, natura solului etc), dar și arhitectural-spațiale, care au potențialul de a satisface condițiile estetice, simbolic-axiologice si culturale ale unei societăți, la un moment dat Aceste ultime condiționări nu sunt nicidecum secundare sau opționale, ele întregind de fapt calitățile arhitecturale ale unui ansamblu spațial, devenind astfel esențiale în procesul de creație.

Expresivitatea unei anumite structuri este corelata permanent $\mathrm{cu}$ mentalitățile anumitor grupuri profesionale direct implicate în acest proces de selectie (arhitecti, ingineri, matematicieni, artisti plastici etc), și fluctuează sau se modelează în concordantă cu acestea. Structurile devin "speciale" atunci când își depășesc propriul statut standard, primar (structuri utilizate tradițional), dezvoltând și o coordonată estetică de anvergură, atipică sau proiectată prin comandă unică. De aici, expresivitatea unei structuri se poate conjuga perpetuu, în mod creativ, având potențialul de a deveni reprezentativă spațial și arhitectura Standardul, reprezentat aici de planurile orizontal și vertical (adică de un grid), este depășit, transformat, modelat sau chiar negat: diagonala este cea care transcrie noul cod (a se citi noul grid), căci ea preia multiplele direcții de forță intermediare generate între cele două planuri originare.
Fără a avea pretenția exhaustivă de a descrie această temă (ale cărei resurse sunt inepuizabile și permanent recreate), vom puncta câteva tipuri de expresie structurală, care sunt generate de configurații sau morfologii atipice:

\section{pânzele subțiri}

Anvelopante fluide, flexibile, ușoare și subțiri, din membrane tensionate prin cabluri si sisteme structurale variate (inele de armătură, rețele metalice structurale, care generează geometrii spațiale de anvergură (adesea devin landmark pentru zona în care sunt amplasate). Vezi și Skysong at ASU Campus, FTL Design Engineering Studio (Scottsdale, 2009) / membrană PTFE din fibră de sticlă, $50.000 \mathrm{mp}$ sau Shanghai 2010 Bulevard, SBA International Architects (Shanghai, 2010) - cea mai amplă membrană anvelopantă din lume (2010), cu suprafața de $65.000 \mathrm{mp}$ (dublă membrană)

(Fig.1-3 Proiect de Structuri complexe (UAUIM, anul V/2019-2020, stud.arh. Teodor Dascălu, Vlad Nicolescu, Atelier 52: Prof.dr.arh. Dan Serban, Lect.dr.arh. Mihaela Zamfir, Lect.dr.arh. Ana-Maria Vesa-Dobre, arh. Simina Dron) 


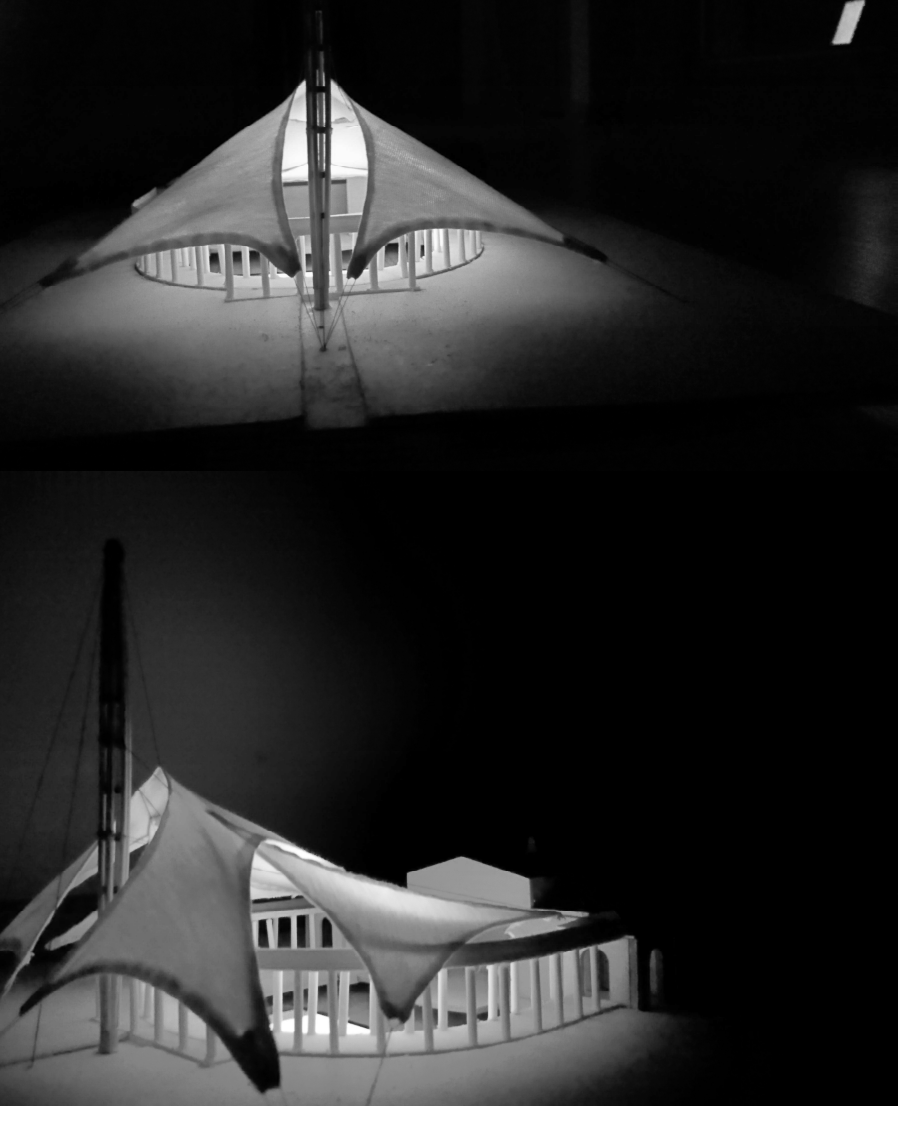

\section{structuri mimetice}

Arhitectura secolelor XX-XXI a prezentat adesea diverse aspecte mimetice, de la Art Nouveau sau Art Deco la Postmodernism și Neomodernism, cu variate influențe de imitație (structuri vegetale, geometrice, florale sau animale etc). Acest aspect a depins și de o oarecare teatralitate sau scenografie a formelor. În secolul XXI, mimetismul se regăsește preponderent în arhitectura mișcării (forme în zbor, forme în mișcare accelerată), dar și în diverse structuri naturale (vegetale, organice, biologice), la micro- sau macro-scară de reprezentare.

Vezi și: Ingalls Skating Ring, Eero Saarinen (1958, Conneticut, USA) the 'Yale Whale' / structura este ancorată în "coloana vertebrală a balenei", realizată din beton armat pre-tensionat, iar anvelopanta $\mathrm{cu}$ dublă curbură este suspendată pe cabluri, din acest "os" central (sau coastă). Deși cumva brutalistă și aspră, structura anvelopantei este atenuată de căldura lemnului de stejar al panourilor interioare și de forma masivă, dar zveltă, care pare că plutește peste ringul de patinaj si sticla perimetrală.

New Amsterdam Pavilion, UNStudio (NY, 2009) / mimetism floral, regăsit și în conceptul modular al pavilionului („petalele” structurale se asamblează într-un nucleu central, asemenea formelor vegetale)

Fig.1-3* Proiect de Structuri complexe (UAUIM Universitatea de Arhitectură și Urbanism Ion Mincu București, anul V/2019-2020, stud.arh. Teodor Dascălu, Vlad Nicolescu, Atelier 52: Prof.dr.arh. Dan Șerban, Lect.dr.arh Mihaela Zamfir, Lect.dr.arh. Ana-Maria Vesa-Dobre, arh. Simina Dron)

Fig.1-3* Student Project, Complex Structures (Ion Mincu University of Architecture and Urbanism, 5th year of study/2019-2020, stud.arch. Teodor Dascălu, Vlad Nicolescu, Atelier/Studio 52: Prof.Dr.Arch. Dan Serban, Lect.Dr.Arch. Mihaela Zamfir, Lect.Dr.Arh. Ana-Maria Vesa-Dobre, Arch. Simina Dron)

*Imagini și credite transmise de autor Vesa-Dobre A-M. pentru publicarea articolului / Images and credits sent by the anvelopante și structuri lichefiate

Deconstrucția monoliticului și lichefierea solidelor volumele nu mai apar ca mase compacte, rigide, statice, ci se dizolvă în forme "lichide”, fluide, organice, care se pliază pe diverși parametri (functiune, mediu, tehnologie); este și forma specifică mișcării (fie a automobilului în viteză, o aerodinamică arhitecturală orizontală, fie cea a navei spațiale în zbor - verticala „topită”) (Fig.4-6)

\section{anvelopante și structuri riglate}

Adesea bazate pe formele origami, se pliază, sunt modulare și compacte, pot fi folosite și în combinații cu module rotite, pentru a genera forme complexe, sunt mobile (portabile) și ușoare, prefabricate, se transformă, oferă dinamism și anvergură spațiului în care sunt amplasate. Vezi și Kiosk, Make Architects (2014, Londra), Grand Stade de Casablanca, NBB Studio (2011, Maroc)

\section{anvelopante și structuri generate prin mișcări de} rotație

Mișcarea de rotație implică o legătură interiorexterior, care se dezvoltă spațial perpetuu volumele devin dinamice și sugerează o inerție virtuală a mișcării propriu-zise; rotațiile mai complexe generează forme spațiale cu atât mai elaborate cu cât parametrii mișcării imprimate de distorsiunea volumului sunt mai variate: Art 615 Aalborg University Students experiments (2010 Danemarca/ Denmark 
Fig.4* MAAT Lisabona, arh. Amanda Levete | ………….............. Foto: arh. Marina Mihăilă (arhiva personală)

Fig. $4^{\circ}$ MAAT Lisbon, arch. Amanda Levete |

Photo: Arch. Marina Mihăilă (private archive)

Fig.5-6* Chanel Pavilion, Zaha Hadid (2008-2010, Paris) -

structură aluminiu, membrană PVC cu fibre de plastic

armată, ETFE membrane iluminante. Foto: arh. Ana Vesa

Fig.5-6* Chanel Pavilion, Zaha Hadid (2008-2010, Paris) Aluminum structure, PVC membrane, reinforced with fibreglass, ETFE lightened membrane. Photo: arch. Ana Vesa

*Imagini și credite transmise de autor Vesa-Dobre A-M. pentru publicarea articolului / Images and credits sent by the author Vesa-Dobre A-M. for article's publication
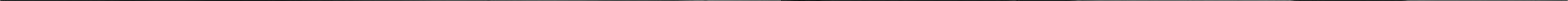


\section{structuri-instalații}

La interferența dintre arhitectură și artele vizuale (scenografie urbană, muzică, grafică de imagine computerizată etc), dar și arhitectură-științe (matematică, inginerie arhitecturală și de sunet etc) instalațiile sunt o manifestare urbană a acesto confluențe; ele „mobilează” și „mobilizează” adesea spațiile urbane deschise, devenind repere sau mici accente dinamice, menite a transfigura diverse puncte de atracție din oraș. Vezi și: Acoustic Formations, Salon 2 (2012, Instanbul)

Prezentarea acestor tipuri de configurații spațiale nu are pretenția de a epuiza tema, cu atât mai puțin tendințele acesteia, ci doar punctează câteva dintre aspectele predominante ale subiectului. Ideile descrise aici au fost dezvoltate parțial și în prelegerile anterioare de atelier (anii univ. IV-V, între 2013 și 2018), pentru proiectele de Pavilion experimental (Cameră urbană), Info-Point, Catalizator urban (K) și Sală de sport (Clădiri cu structuri complexe și deschideri mari), fiind o sursă bună de familiarizare a studenților cu noile programe sau cu tehnologii recente, utilizate în domeniu, dar si un bun punct de pornire în demersul lor conceptual. (english version)

Any architectural structure is designed as a set of horizontal and vertical elements, interconnected in order to assure specific volume strength, against any exterior stress (gravitational weight, usual functional loads, including those from partitions and installations, wind, snow, earthquake etc). Within the design process, selecting a certain type of spatial structure is therefore related to several factors, simultaneously accepted as necessary: physical resistance, technical data and constraints, environmental and climatic features (site circumstances, soil nature etc), as well as spatialarchitectural conditions, liable to meet other specific demands, such as esthetic, symbolic-axiological and cultural criteria of a certain society at a certain given time. The latter are by no means secondary, nor optional, being in fact the ingredients for architectural quality of any spatial ensemble, thus becoming essential within the creative process.

The poetry of any structure has always been linked with certain professional group mentalities, directly involved within this selection process: architects, engineers, mathematicians, artists and so on. This expression shifts and gets shaped in accordance to these mentality dynamics. The structures become "atypical" whenever they transcend their own standard or elementary status (as traditional structures), while developing in the same time a farreaching esthetical feature, non-standard or designed upon specific order. Hence, the expressiveness of unique structures may be creatively and perpetually conjugated, having the potential of becoming spatial and architectura representative. The standard, rendered here as horizontal and vertical planes (such as a grid) is surpassed, trans-formed, shaped or even denied: 
since the diagonal line is the one writing the new code (as in, the new grid), taking over the multiple transitional force lines, generated by the two, original planes.

Evolving this topic without exhaustive claim (since its resources are never ending and constantly recreated), we will mark some poetic structural typologies, generated by atypical configuration and morphology:

\section{tensile membrane structures}

Fluid envelopes, flexible, light and thin, made of tensile membranes and cold-formed carbon support structures, highly-engineered, customized cables and fittings; they generate far-reaching spatial geometry and often become a landmark for the area they populate. See also: Skysong at ASU Campus, FTL Design Engineering Studio (Scottsdale, 2009) / PTFE fiber-glass membrane, 50.000 sqm, or Shanghai 2010 Boulevard, SBA International Architects (Shanghai, 2010) - the largest membrane envelope in the world (2010), with $65.000 \mathrm{sqm}$ surface (double membrane)

(Fig.1-3, Student Project, Complex Structures, UAUIM, $5^{\text {th }}$ Year 2019-2020, stud.arch. Teodor Dascălu, Vlad Nicolescu, Atelier 52: Prof.PhD.Arch. Dan Șerban, Lect.PhD.Arch. Mihaela Zamfir Lect.PhD.Arch. Ana-Maria Vesa-Dobre, arh. Simina Dron)

\section{mimetic structures}

The 20th-21st century architecture has often been mimetic, in various aspects, from Art Nouveau and Art Deco to Postmodernism and NeoModernism, with several influences of imitation (vegetal structures, floral or animal geometries, natural landscapes etc). This mimesis also led to a certain theatricality or scenography of form. In early 21st century, the mimetic structures is mostly found in the architecture of movement (flying forms, accelerated movement structures), as well as in various natural structures (micro-scale organic structures, biological zoom-in details or macro-scale landscape, such as galactic spatial scenes etc).

See also: Ingalls Skating Ring, Eero Saarinen (1958, Conneticut, USA) the 'Yale Whale' / the structure is anchored within the "whale's spine", designed in pre-tensioned reinforced concrete, while the double curve envelope is suspended on cables, across this axial "bone" (or "rib"). Although brutalist and rough, the envelope structure is smoothed by the warm wooden interior panneling (oak) and the massive shape, that somehow feels supple and floating over the skating ring and perimeter glass. New Amsterdam Pavilion, UNStudio (NY, 2009) / floral mimetism, found as well into the modular concept of the pavilion (its structural "petals" are connected into the central core, likewise many vegetal shapes

\section{liquefied structures and envelopes}

They render the deconstruction of the "traditional" monolith and embrace the solids liquefying: the volumes no longer appear as compact, rigid, static masses, but rather dissolved into "liquid" shapes; fluid, organic spaces that fold according various parameters (function, environment, technology). It is also the specific form of movement (either the fast automobile, as horizontal architectural aerodynamics, or the rising spatial craft - as the "melted" vertical) Fig.4-6.

\section{origami envelopes and structures}

These shapes are folding in and out, designed as modular and compact spaces that may be used as such or combined, in order to generate complex shapes; they are mobile (portable) and light, prefab- 
structures that transform and offer dynamic views and spatial reference for their location. See also: Kiosk, Make Architects (2014, London), Grand Stade de Casablanca, NBBJ Studio (2011, Maroc).

\section{rotation envelopes and structures}

The rotation movement implies an interior-exterio connection, spatially developed in order to describe dynamic volume perception, suggesting in the same time a virtual inertia of the movement itself. The more complex rotation generates more elaborated spatial shapes, as effects of the induced movement (enhancing the illusion of never-ending rotation; the volumes appear as cut in a certain stage of the movement, rather than in a balanced position). As seen in Art 615, Aalborg University Students experiments (2010, Danemarca/ Denmark)

\section{installation- structures}

At crossroads between architecture and visual arts (urban scenography, music, digital graphics, street art etc), as well as between architecture and science (mathematics, architectural and sound engineering etc), the installations are an urban symptom of these confluences; they often "furnish" and "mobilize" the open, public urban spaces, becoming landmarks or points of dynamic reference, meant to display attractive pieces of entertainment in the city (As seen in Acoustic Formations, Salon 2 (2012, Instanbul).

In the end, the presentation does not exhaust the theme, nor its tendencies, but rather points out some general lines of the subject. Some of these ideas were also described in the previous studio lectures of the 4th and 5th years (2013 - 2018), involving the projects Experimental Pavilion / Urban Room, Info-Point, K Urban Catalyser and Sports Hal (Complex Structure and Wide-Span Buildings). They proved to be a good starting reference point for the students, while they were getting accustomed to the new typologies of programes and recent structure developing technologies. For their conceptual approach, the lectures were intended to guideline the topic specific tendencies, being joined with model research and studies, at various scales and detail.

\section{Referinte articole web / References web articles}

*https://www.archdaily.com/31562/skysong-at-asu-campus-ft|design-engineering-studio

*https://www.archdaily.com/57749/shanghai-2010-boulevardknippers-helbig/5008f1b228ba0d27a7000e22-shanghai-2010-

boulevard-knippers-helbig-image

*https://www.archdaily.com/157708/ad-classics-david-s-ingallsskating-rink-eero-saarinen

*https://www.unstudio.com/en/page/3198/new-amsterdamplein-pavilion

*http://www.evolo.us/fibre-composite-adaptive-systems/ *arhiva privată autor/ autor's private archive

*https://www.makearchitects.com/projects/canary-wharf-

kiosks/,

*https://www.archdaily.com/179243/grand-stade-de-

casablanca-nbbj-yassir-khalil-studio/parametric-structure

*https://www.archdaily.com/59960/art615-a-pavilion-byaalborg-university-students,

https://socialtechnologies2010.wordpress.com/?utm_medium = website\&utm_source=archdaily.com

*https://www.archdaily.com/195925/augmented-structures-v11-acoustic-formations-salon2

Citare articol curent / Citation:

(Ro)

Vesa-Dobre A-M. (2021). Expresivitatea structurilor spatiale atipice. în Teoria proiectului de arhitectură. Idei construite. SP FA UAUIM. EUIM - Editura Universitară Ion Mincu, București. (En)

Vesa-Dobre A-M. (2021). The expressivity of atypical spatial structures. in Architectural design theory. Built ideas. SP FA UAUIM. EUIM - Ion Mincu University Publishing House, Bucharest. 
